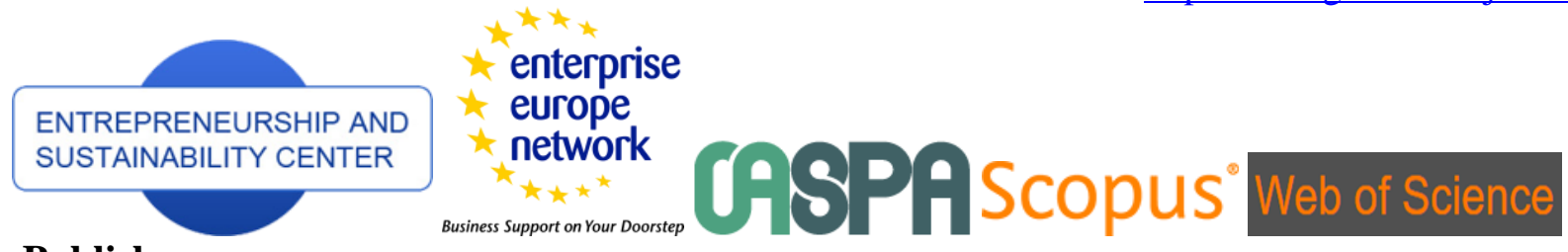

Publisher

$\underline{\text { http://jssidoi.org/esc/home }}$

1) Clarivate

Analytics

\title{
THE INVESTMENT COMPONENT IN A NATION'S ECONOMIC SECURITY: THE CASE OF THE RUSSIAN FEDERATION
}

\author{
Marina Gennadievna Nikitina ${ }^{*}$, Viktoriya Viktorovna Pobirchenko², Elena Alekseevna Shutaieva ${ }^{3}$, \\ Anna Ivanovna Karlova ${ }^{4}$ \\ 1,2, 3, 4 V.I. Vernadsky Crimean Federal University, Prospekt Vernadskogo, 4, Simferopol, Russian Federation, 295007 \\ E-mails: : ${ }^{1}$ nikitina_crimea@mail.ru, ${ }^{2}$ viktoriya_crimea@list.ru, ${ }^{3}$ shutaeva2003@mail.ru,.ㅁa.karlova@mail.ru
}

Received 20 August 2018; accepted 15 November 2018; published 30 December 2018

\begin{abstract}
The purpose of this paper is to provide a characterization of the current state and level of the investment component in Russia's economic security and concretize the key focus areas for ensuring it. The study is grounded in the dialectical method of scientific cognition, the method for cognizing the process of attaining investment security in all its contradictions, integrity, and development, as well as the systemic approach to the analysis of the effect of investment activity on the national economy. The authors explore some of the key theoretical aspects of investment security within the national economy and examine the dualism of investment security as a component in the nation's economic security; establish a system of indicators for ensuring investment security, including its major qualitative and quantitative criteria; compute a set of indicators for the investment component in economic security; identify some of today's key threats to investment security within the Russian economy. Exploring the theoretical aspects and computing the indicators of investment security serve as a basis for further research into the subject and may help detect and minimize threats that may arise in connection with the investment process, as well as develop and concretize a set of major focus areas for ensuring investment security at all levels.
\end{abstract}

Keywords: economic security; investment process; investment risks; investment security; Russian Federation

Reference to this paper should be made as follows: Nikitina, M.G.; Pobirchenko, V.V.; Shutaieva, E.A.; Karlova, A.I. 2018. The investment component in a nation's economic security: the case of the Russian Federation, Entrepreneurship and Sustainability Issues 6(2): 958-967. http://doi.org/10.9770/jesi.2018.6.2(32)

JEL Classifications: E22, O10

\section{Introduction}

The globalization of international economic relations, which has become a distinctive trait of our civilization's development in the 21 st century, has given rise to a number of new categories in both the political and economic spheres, which now require scholarly conceptualization and substantiation. Among the more significant concepts is a nation's economic security. "Economic security may be construed as a state of the national economy where, through the effective and integrated use of available resources (natural, material, financial, labor, administrative, and political/legal), as well as a system of state activities and measures, there can be achieved the optimum level 
of protection for it from external and internal threats through boosting the competitiveness of domestically manufactured products, the nation's defense capability, and people's living standards and quality of life and attaining progress in the economic, social, demographic, and other spheres” (Bart 2011).

A major component part of economic security is investment security, which can help achieve the integrity of the nation's economic system and its economic security.

Accordingly, there is relevance in conducting integrated research into issues related to fostering the investment security of the national economy and ensuring state regulation of it, with a subsequent focus on resolving relevant practical objectives on ensuring it in the Russian Federation.

\section{Literature review}

Quite a broad spectrum of issues related to the economic substance, structure, functions, and methods of investment security have found reflection in recent literature (e.g. Bikas, Saponaite 2018; Shvetsova et al. 2018; Kuril 2018; Tvaronavičienė 2018a; 2018b; Načisčionis et al. 2018; Katina et al. 2018; Muhtar et al. 2018).

The above-mentioned authors have made a significant contribution to the development of research on the subject. However, the theory of economic security, as well as issues related to working out and enhancing the investment mechanism for ensuring it, still need concretization. There is also a need for whole new approaches to describing the influence of investment activity on crucial social/economic processes taking place in Russia that are related to boosts in its economic security.

\section{Methods and the study's mission}

The study is grounded in the dialectical method of scientific cognition, the method for cognizing the process of attaining investment security in all its contradictions, integrity, and development, as well as the systemic approach to the analysis of the effect of investment activity on the national economy.

The study's methodological basis is sets of general scholarly and philosophical approaches (systemic, synergetic, structural/functional, etc.) and methods (scholarly abstraction, comparative, graphic representation, etc.). The authors also employ certain statistics methodologies.

The study's purpose is to provide a characterization of the current state and level of the investment component in Russia's economic security and concretize the key focus areas for ensuring it.

\section{Results and discussion}

Investment security within the national economy is a type of economic security that ensures the reproductive nature of the economy, thus acting as a "system of investment relations within the economic system aimed at the enhancement and further development of investment processes, most importantly at ensuring the stability, sustainability, and independence of investment activity within the national economy" (Litvinov \& Buzin 2008).

Investment security is of a dual nature: on the one hand, it is a component part of the system of ensuring economic security, while, on the other hand, it maintains a relative amount of independence due to the special nature of investment activity.

Investment security, as a component part of economic security, takes on the role of a regulator that coordinates the movement of investments. In this context, the process of ensuring investment security is joined by financial 
The International Journal

ENTREPRENEURSHIP AND SUSTAINABILITY ISSUES

ISSN 2345-0282 (online) http://jssidoi.org/jesi/

2018 Volume 8 Number 2 (December)

http://doi.org/10.9770/jesi.2018.8.2(32)

security. Interaction among the entities is regulated by the various forms of control. On the part of the government, it is taxation, financial, and administrative control. Nongovernmental entities exercise control through special institutions (e.g., audit firms and courts of arbitration) and federations (associations, leagues, guilds, unions, and movements). The specific forms of control form a chain of two-way communication that enables making adjustments to previously set objectives to ensure the maximum effectiveness of the system's operation.

The system of ensuring investment security is comprised of a set of interrelated and coordinated elements which directly influence it. The key elements include:

1. The political element, which is reflected in the direct dependence of the volumes of investment coming in into the country on the level of its geopolitical influence, the activity of political movements within it, and other countries' foreign policies toward it.

2. The economic element, which is expressed through the dependence of innovation activity in the country on its geoeconomic influence in the global arena, the state of its economy, and its system of regulation and stimulation/restriction in the area of investment activity using economic methods.

3. The social element, which is expressed through the demographic situation in the country, its gender-and-age structure, its population's education levels, and its levels of social support. The focus here is on having sufficient labor resources with relevant education and qualification levels.

4. The innovation element, which is reflected in the interrelationship between investment attractiveness for potential investors and the availability of cutting-edge technology in the country (as well as its ability to access it), its level of scientific activity, and its level of development of innovations. Having in place a sound innovation element may help maximize the effect from production activities, as well as minimize the costs, based on the effective implementation of technology.

5. The environmental element, which is of the least significance to most investors and the state as a whole due to the nation's imperfect legislation in the area of environmental conservation and protection, the high costs of implementing eco-friendly technology, and the focus on more important issues.

The system of indicators for ensuring investment security includes a set of qualitative and quantitative criteria. The quantitative indicators must be aligned with appropriate criteria and metrics. Table 1 lists a set of appropriate threshold values for these indicators.

Table 1. Indicators of the Nation's Investment Security

\begin{tabular}{|l|c|c|c|}
\hline \multicolumn{1}{|c|}{ Indicator } & Measurement units & Threshold values & Restrictions \\
\hline Total GDP relative to the G7 average & $\%$ & 75 & Not less than \\
\hline Investment in the economy, $\%$ & $\%$ of GDP & 25 & Not more than \\
\hline Inflow of foreign investment into the economy, $\%$ & $\%$ & 5 & Not more than \\
\hline Outflow of investment from the economy, $\%$ & $\%$ & 5 & Not more than \\
\hline Investment in fixed capital stock, $\%$ & $\%$ & 10 & Not less than \\
\hline Share of foreign investment in total investment, $\%$ & $\%$ & 25 & Not more than \\
\hline
\end{tabular}

Source: Compiled by the authors based on data from S.Yu. Glazev (1997)

The authors employed the following indicators of investment security and methods for computing them (Shchegolev \& Shakhov 2009; Nikitenko \& Bulavko 2009, p. 77):

1. Total GDP relative to the G7 average. This indicator helps determine how much Russia is lagging behind the G-7 nations in GDP growth (1.1):

$$
\frac{\mathrm{GDP}_{n} \times 10096 \times 7}{\sum_{\mathrm{G} 7} \mathrm{GDP}_{n}}
$$

where $\mathrm{GDP}_{n}$ is Russia's GDP in the n-th year; 7 is the number of countries in the group; $\sum_{\mathrm{G} 7} \mathrm{GDP}_{n}$ is the sum of the GDPs of the countries in the group in the $n$-th year. 
2. Investment in the economy. This indicator helps assess the investment yield in the period from the time the funds were invested in the economy to the present time (1.2)

$$
\frac{\mathrm{TI}_{n}}{\operatorname{GDP}_{n}} \times 100 \%
$$

where $\mathrm{TI}_{n}$ is the total investment in the economy in the $\mathrm{n}$-th year.

3. Inflow of foreign investment into the economy. This indicator helps determine the degree to which the nation depends on foreign investment coming in into the economy (1.3):

$$
\frac{\mathrm{TI}_{\mathrm{IN}}}{\mathrm{GDP}_{n}} \times 100 \%
$$

where $\mathrm{TI}_{\mathrm{IN}_{n}}$ is the volume of foreign investment in the economy in the n-th year.

4. Outflow of investment from the economy. This indicator helps determine the structural changes within the economy caused by investment flowing out of the economy (1.4):

$$
\frac{\mathrm{TIOUT}_{n}}{\mathrm{GDP}_{n}} \times 100 \%
$$

where $\mathrm{TI}_{\mathrm{OuT}_{n}}$ is the volume of investment that flowed out of the economy in the $\mathrm{n}$-th year.

5. Investment in fixed capital stock. This indicator characterizes a period in which there took place the complete restoration of fixed capital stock based on the attraction of investment for restoring it (1.5):

$$
\frac{\mathrm{TI}_{n}}{\operatorname{TFCS}_{n}} \times 100 \% \text {, }
$$

where $\mathrm{TFCS}_{n}$ is the total fixed capital stock in the n-th year.

6. The share of foreign investment in total investment. This indicator characterizes economic activity by foreign investors within the nation's economy (1.6):

$$
\frac{\mathrm{TI}_{I N_{n}}}{\mathrm{TI}_{n}} \times 100 \%
$$

The indicators of investment security must be computed in comparable quantities (e.g., billion rubles) and based on a certain time period (e.g., year). In the event data are not available on one of the criteria, no calculations can be performed for the period, which, consequently, renders it impossible to draw any valid inferences.

In the event an indicator under analysis differs from the threshold value significantly (for the worse), it may be possible to speak of potential threats to investment security. Investment threats, or threats to investment security (investment activity), are factors within the economic system that have negative impact on investment activity, can minimize the positive effect from investment activity, or result in a negative effect. Risks to investment security at the level of a country are, mainly, of a general nature. When a nation is highly dependent on global processes, considerable impact may come from general foreign economic risks, as, for instance, is the case with the current sanctions pressure on Russia.

Any kind of activity that has a commercial basis to it requires funding, which can be internal and external. At the level of the state, internal funding implies the use of the state's own funds (e.g., the state budget and public funds), while external funding deals with attracting funds from a third party (e.g., investors, commercial private funds, and loans). Attracted funds, except for charity-based and unremunerated contributions, are, normally, the better option for the state, as any investor will pursue commercial gains in the form of a percentage of revenue from a project, stock dividends, etc. This may, also, foster the economy's dependence on and the need for continual boosts in investment.

Fig.1 illustrates the dynamics of investing in fixed assets in Russia across the key sources of funding. 


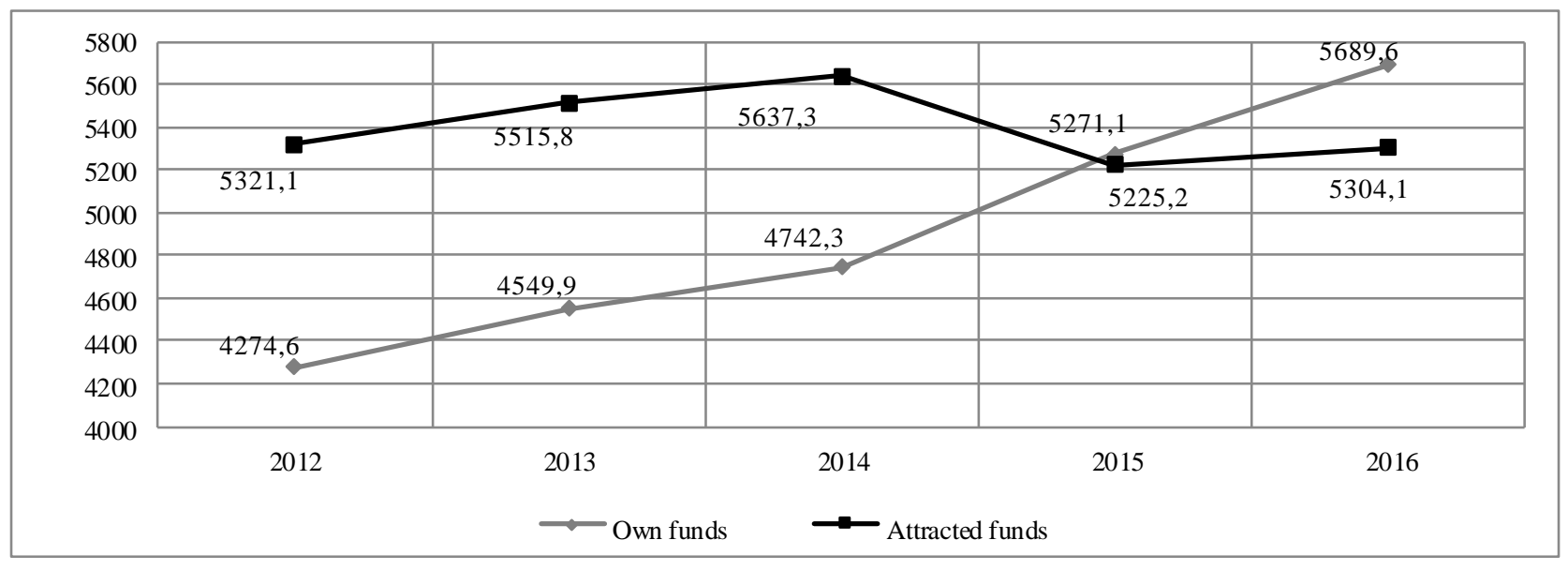

Fig.1. Investment in fixed assets in Russia across the key sources of funding (2012-2016), billion rubles

Source: Compiled by the authors based on data from the Russian Federal State Statistics Service (n.d.)

The authors' analysis indicates that up to 2015 the main source of funding investment in fixed assets in Russia was attracted funds. Only in 2016 things began to shift toward the use of own funds. The lack of own investment may be conducive to a risk of the economic situation worsening and a threat to investment security (and afterwards economic security, as a whole).

A crucial condition for stability in the country is all-round development. In a climate of sanction restrictions and amid the active pursuit of a policy of import substitution, investment is needed today with respect to all types of economic activity in Russia. However, the nation has for years experienced an imbalance across the sectors of the economy. The key focus in terms of investment attractiveness has long been on the following sectors: extraction of mineral resources, agriculture, including hunting, forestry, and fisheries, and, somewhat less, on manufacturing activities (Table 2). However, at the current stage in the development of the global economy, these types of activity are increasingly becoming less sought-after, and in Russia that is coupled today with a poor innovation and technological component.

Table 2. Investment in Fixed Assets in Russia across the Key Types of Economic Activity (2012-2016), billion rubles

\begin{tabular}{|c|c|c|c|c|c|}
\hline \multirow{2}{*}{ Type of activity } & \multicolumn{5}{|c|}{ Year } \\
\hline & 2012 & 2013 & 2014 & 2015 & 2016 \\
\hline Agriculture, hunting, forestry, fisheries, and aquaculture & 488.6 & 530.9 & 525.5 & 520.2 & 627.6 \\
\hline Extraction of mineral resources & $1,858.4$ & $2,004.0$ & $2,144.8$ & $2,385.2$ & $2,830.4$ \\
\hline Manufacturing activities & $1,688.7$ & $1,945.3$ & $2,084.6$ & $2,172.6$ & $2,123.7$ \\
\hline Production and distribution of electric power, gas, and water & $1,166.0$ & $1,187.6$ & $1,186.2$ & 980.0 & 940.2 \\
\hline Construction & 348.6 & 438.1 & 469.3 & 401.2 & 445.0 \\
\hline Wholesale and retail trade; repair of motor vehicles, motorcycles, household goods, and personal appliances & 456.0 & 517.9 & 554.6 & 542.8 & 632.7 \\
\hline Transport and communications & $3,330.7$ & $3,288.6$ & $2,981.0$ & $2,499.7$ & $2,726.7$ \\
\hline Real estate operations, leasing, and provision of services & $1,968.0$ & $2,195.7$ & $2,701.4$ & $3,161.4$ & $3,018.3$ \\
\hline
\end{tabular}

Source: Compiled by the authors based on data from the Russian Federal State Statistics Service (n.d.) 
The International Journal

ENTREPRENEURSHIP AND SUSTAINABILITY ISSUES

ISSN 2345-0282 (online) http://jssidoi.org/jesi/

2018 Volume 8 Number 2 (December)

http://doi.org/10.9770/jesi.2018.8.2(32)

The low levels of diversification of investment are posing a serious danger to the nation's economic security as a whole, giving rise to disproportions in its economic development.

The authors evaluated the current state of investment activity in Russia by analyzing a set of relevant indicators (Table 3).

Table 3. Key Indicators Influencing Investment Volumes in Russia (2012-2016), \%

\begin{tabular}{|l|c|c|c|c|c|}
\hline \multirow{2}{*}{ Indicator } & \multicolumn{5}{c|}{ Year } \\
\cline { 2 - 6 } & 2012 & 2013 & 2014 & 2015 & 2016 \\
\hline Total investment, billion rubles & $12,586.109$ & $13,450.23$ & $13,902.64$ & $13,897.18$ & $14,639.83$ \\
\hline FDI imports into Russia, billion rubles & 905.63 & $1,655.31$ & $1,020.31$ & 589.49 & N/A \\
\hline FDI exports from Russia, billion rubles & 852.68 & $2,191.23$ & $2,247.09$ & $1,593.49$ & N/A \\
\hline Cost of fixed capital stock, billion rubles & $121,268.9$ & $133,521.53$ & $147,429.65$ & $160,725.26$ & N/A \\
\hline GDP, billion rubles & $66,926.86$ & $71,016.72$ & $79,199.65$ & $83,232.61$ & $86,043.64$ \\
\hline
\end{tabular}

Source: Compiled by the authors based on data from P.G. Nikitenko and V.G. Bulavko (2009) and the Russian Federal State Statistics Service (n.d.)

Among the above indicators, the greatest concern is the low level of foreign direct investment in the economy's real sector, while there are increases in portfolio investment. On top of that, today "foreign capital is being concentrated in the nation's export-oriented sectors, which is further exacerbating deformations in the Russian economy" (Litvinov \& Buzin 2008). Some of the threats in the area of investment security include low levels of increase in investment as opposed to GDP growth. "In reality, there may be observed a mutual effect between revenue and investment. Due to the multiplier effect, autonomous investment, as an initial "injection", leads to a boost to GDP, which, logically, is followed by an increase in the propensity to invest in society (induced investing). This may help boost economic growth rates based on the accelerator effect. A combination of the multiplier and accelerator effects provides the multiplier/accelerator effect (the Hansen-Samuelson model)" (Zhdanova 2015). It may be worth giving separate consideration to the GDPs of the G-7 nations and Russia. This indicator is central to the study of the nation's overall economic security, as it encompasses virtually all processes and changes taking place within its economy. Taking a more global approach to investigating the indicator may help determine the nation's current geoeconomic and geopolitical status in the global arena. Table 4 helps explore the dynamics of the GDPs of the G-7 nations and the Russian Federation in the period 2012-2016 through an analysis of relevant data and trends and comparisons with the threshold value.

Table 4. Dynamics of the GDPs of the G7 Nations and Russia (2012-2016), trillion US dollars

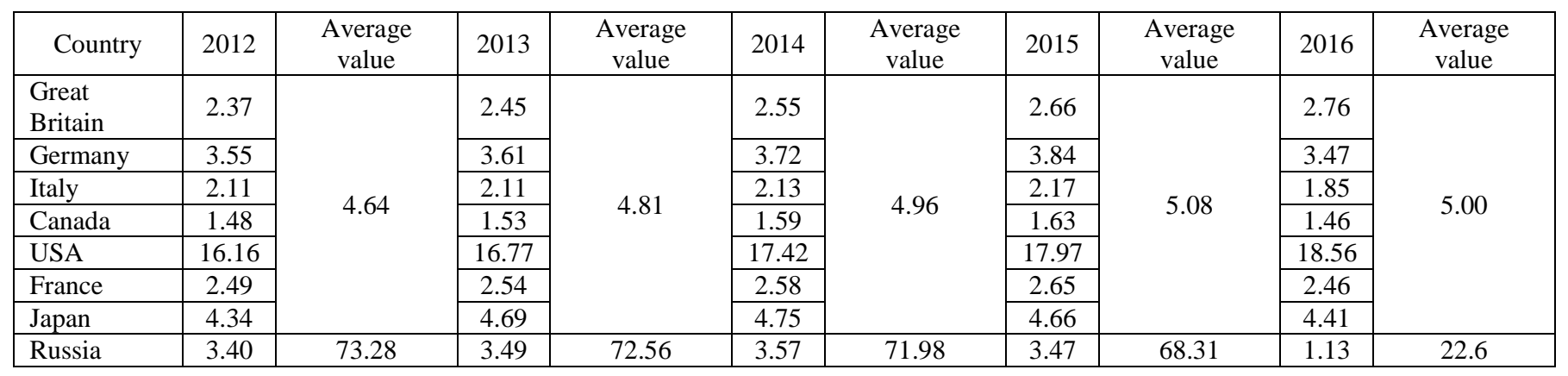

Source: Computed and compiled by the authors based on data from the International Monetary Fund (n.d.) 
The first factor that is central to the study of the above indicator is the difference between trends in the growth of Russia's GDP based on data from the Russian Federal State Statistics Service (Rosstat) and from the International Monetary Fund (IMF). According to data from the IMF, Russia's GDP kept growing up until 2014, and after that it started to decline. Based on data from Rosstat, the nation's GDP was growing year by year, without any declines. Here, the indicator has been affected by the factor of inflating the indicators to ensure a match to federal development programs and charted courses for national development. This technique has long been widely employed in many countries around the world. Today's global space is characterized by an economic race among nations, with many of them lobbying for their own interests in the geopolitical and geoeconomic arenas. In the case of the IMF, a nation that is actively engaged in the pursuit of its own interests is, above all, the United States. Thus, it cannot be stated objectively that the comparative analysis by the IMF is more credible than that by Rosstat.

The authors computed the average GDP for the G-7 nations and compared the figure with the value for Russia in percentage terms. This indicator demonstrated a trend toward decrease in the period 2012-2016. Between 2012 and 2016 , there was a decline of $50.68 \%$. The greatest decline was recorded in $2015-45.71 \%$. The threshold value for this indicator is not less than $75 \%$. With that said, in contrast with the period 2012-2014, when the threat to economic security was only in its incipience, in 2016 it turned into a major problem, with the nation falling behind on a number of general global trends under the pressure of sanction restrictions and amid cooling relations with certain nations.

In order to be able to directly compute the dependence of the state of the nation's economic security on its investment component, it is necessary to compute the key coefficients for this group of indicators: investment in the economy, inflow of foreign investment into and outflow of investment from the economy, investment in fixed capital stock, and share of foreign investment in total investment. The coefficients are computed based on the data mentioned earlier in this work (Table 4). The actual values are to be compared with the threshold ones. If an indicator deviates from the threshold value, depending on the direction of deviation, it may be possible to speak of there being a threat to the nation's economic security within this area with the group of investment indicators. Any deviation on the part of the indicators within the group of investment coefficients may have significant impact on the nation's economic security, as is evidenced in Table 5 below.

Table 5. Actual and Threshold Values for Indicators of the Investment Component in Russia's Economic Security (2012-2016), \%

\begin{tabular}{|l|c|c|c|c|c|c|}
\hline \multicolumn{1}{|c|}{ Coefficient } & \multirow{2}{*}{ Threshold value } & \multicolumn{5}{c|}{ Actual value } \\
\cline { 3 - 7 } & & 2012 & 2013 & 2014 & 2015 & 2016 \\
\hline Investment in the economy, \% & $\leq 25$ & 18.81 & 18.94 & 17.55 & 16.70 & 17.01 \\
\hline Inflow of foreign investment into the economy, \% & $\leq 5$ & 1.35 & 2.33 & 1.29 & 0.71 & N/A \\
\hline Outflow of investment from the economy, \% & $\leq 5$ & 1.27 & 3.09 & 2.84 & 1.91 & N/A \\
\hline Investment in fixed capital stock, \% & $\geq 10$ & 10.38 & 10.07 & 9.43 & 8.65 & N/A \\
\hline Share of foreign investment in total investment, \% & $\leq 25$ & 7.20 & 12.31 & 7.34 & 4.24 & N/A \\
\hline
\end{tabular}

Source: Computed and compiled by the authors based on data from P.G. Nikitenko and V.G. Bulavko (2009), the Russian Federal State Statistics Service (n.d.), and S.Yu. Glazev (1997)

"The indicators of investment security approaching their maximum admissible values are testimony to an augmenting threat to social stability in society, and exceeding the threshold values - to society entering a zone of instability and social conflicts, in point of fact to, overall, a real threat to economic security" (Nikitina 2011, p. $30)$. 
The International Journal

ENTREPRENEURSHIP AND SUSTAINABILITY ISSUES

ISSN 2345-0282 (online) http://jssidoi.org/jesi/

2018 Volume 8 Number 2 (December)

http://doi.org/10.9770/jesi.2018.8.2(32)

In analyzing and comparing the actual values for the investment component of the nation's economic security, the most efficient method is ranking the indicators. This is due to that, visually, one may be tempted to consider as the most stable a year in which all indicators are the greatest, which is wrong. In ranking the indicators, depending on the direction in which the actual values deviate from the threshold one, each year is assigned a rank, with 1 standing for the best result (a safe direction for development) and 4 denoting the emergence of a threat. The most stable year is the one featuring the smallest sum of the ranks. The choice of a 1-to-4 ranking scheme has to do with the fact that data on the indicators are available only for 4 years: 2012, 2013, 2014, and 2015. There is a lack of up-to-date, credible data for the year 2016, due to which it was possible to compute just one coefficient: investment in the economy. Table 6 provides a ranking of indicators of the investment component in Russia's economic security for the period 2012-2015.

Table 6. Ranking of Indicators of the Investment Component in Russia's Economic Security (2012-2015), \%

\begin{tabular}{|l|c|c|c|c|}
\hline \multirow{2}{*}{ Coefficient } & \multicolumn{4}{c|}{ Actual value } \\
\cline { 2 - 5 } & 2012 & 2013 & 2014 & 2015 \\
\hline Investment in the economy, \% & 3 & 4 & 2 & 1 \\
\hline Inflow of foreign investment into the economy, \% & 3 & 4 & 2 & 1 \\
\hline Outflow of investment from the economy, \% & 1 & 4 & 3 & 2 \\
\hline Investment in fixed capital stock, \% & 1 & 2 & 3 & 4 \\
\hline Share of foreign investment in total investment, \% & 2 & 4 & 3 & 1 \\
\hline Average rank & 2 & 3.6 & 2.6 & 1.8 \\
\hline
\end{tabular}

Source: Compiled by the authors based on data from P.G. Nikitenko and V.G. Bulavko (2009) and the Russian Federal State Statistics Service (n.d.)

The most stable year is 2015, with an average rank of 1.8. However, the year witnessed a shortage of investment in fixed capital stock and a threat of capital flowing out of the economy.

The authors' investigation helped identify the following threats to investment security within the Russian economy:

1. The rate of accumulation being insufficient to enable the Russian economy to shift to a new technological paradigm. According to scholar A.S. Bulatov, galvanizing the modernization of Russia requires a new wave of industrialization and a boost in the rate of gross accumulation to the level of the 1980s - 27-31\% (Bulatov 2011).

2. Low rates of increase in investment compared with GDP growth.

3. Low, and continually falling, figures on foreign investment in fixed assets, while there are increases in portfolio investment.

4. Increased wear and tear on plant and equipment, with the share of totally worn-out plant and equipment having reached a disastrous point, which is resulting in an increased risk of accidents and declines in labor productivity.

\section{Conclusions}

The findings from the authors' study indicate that, under the influence of objective circumstances, it is the investment component that is coming today to the forefront within the system of national economic security. Investment security may be construed as the state's ability to control investment activity by means of relevant economic levers (without exerting too much control over the participants to ensure the autonomy of economic processes) in order to achieve a maximum effect from investment.

Investment security implies interaction with all components in economic security to ensure maximum effectiveness in implementing economic policy within the investment sphere. 
The system of investment security is continually influenced by two major groups of factors: destructive ones, which reduce the overall level of security, and positive ones, which facilitate boosts in investment security and effective economic development.

To summarize the findings from the authors' analysis, the investment component in Russia's economic security is currently in a state of being protected. However, certain events of the last few years (the imposition of economic sanctions, a worsening of geoeconomic and geopolitical impact on the part of certain nations, the need to take part in military operations, etc.) have given rise to a number of threats that need to be minimized and eliminated as soon as possible to help stabilize the nation's economic security and improve its investment image globally. The imperatives for investment security ought to occupy a key place in the area of developing a longterm investment policy. Exploring the theoretical aspects and computing the indicators of investment security (in real time) serve as a basis for further research into the subject and may help detect and minimize threats that may arise in connection with the investment process, as well as develop and concretize a set of major focus areas for ensuring investment security at all levels.

\section{References}

Bart, A. A. 2011. Sovershenstvovanie mekhanizma obespecheniya ekonomicheskou bezopasnosti Rossii v usloviyakh globalizatsii: Monografiya [Enhancing the mechanism for ensuring Russia's economic security in a climate of globalization: A monograph]. Saarbrücken, Germany: LAP LAMBERT Academic Publishing GmbH \& Co.

Bikas, E.; Saponaitè, V. 2018. Behavior of the Lithuanian investors at the period of economic growth, Entrepreneurship and Sustainability Issues 6(1): 44-59. https://doi.org/10.9770/jesi.2018.6.1(4)

Bulatov, A. S. 2011. Vozdeǐstvie eksporta i importa kapitala na valovoe nakoplenie v Rossiǔskoĭ Federatsii [The effect of the export and import of capital on gross capital formation in the Russian Federation], Den'gi i Kredit, 9: 3-8.

Glazev, S. Yu. 1997. Osnova obespecheniya ekonomicheskoi bezopasnosti strany: Al'ternativnyi reformatsionnyi kurs [The basis for ensuring the nation's economic security: An alternative reformative course], Rossiiskii Ekonomicheskii Zhurnal, 1: 3-19.

International Monetary Fund. (n.d.). World Economic Outlook Databases. Available from https://www.imf.org/external/ns/cs.aspx?id=28.

Katina, J.; Sansyzbayeva, G. N.; Guliyeva, A.; Rzayeva, U. 2018. Threats to the country's sustainable economic development: a case study, Journal of Security and Sustainability Issues 8(1): 113-122. https://doi.org/10.9770/jssi.2018.8.1(10)

Kuril, J. 2018. Public administration for safe and secure environment: case of Slovak Republic, Entrepreneurship and Sustainability Issues 5(3): 493-501. https://doi.org/10.9770/jesi.2018.5.3(6)

Litvinov, D. A., \& Buzin, R. V. 2008. Teoreticheskie osnovy investitsionnoĭ bezopasnosti natsional'noĭ ekonomiki [Theoretical foundations of investment security within the national economy], Nauchnye Vedomosti Belgorodskogo Gosudarstvennogo Universiteta: Istoriya. Politologiya. Ekonomika. Informatika, 10(8): 187-192.

Muhtar, M.; Sutaryo, S.; Suryanto, M. 2018. Towards regional sustainable development via government financial transparency: evidence from Indonesia, Journal of Security and Sustainability Issues 7(4): 753-767. https://doi.org/10.9770/jssi.2018.7.4(12)

Načisčionis, J.; Skrastiņa, U.; Tumalavičius, V. 2018. Secure development of public administration, Journal of Security and Sustainability Issues 8(1): 87-102. https://doi.org/10.9770/jssi.2018.8.1(8)

Nikitenko, P. G., \& Bulavko, V. G. (Eds.). 2009. Ekonomicheskaya bezopasnost': Teoriya, metodologiya, praktika [Economic security: Theory, methodology, practice]. Minsk, Belarus: Pravo i Ekonomika. 
The International Journal

ENTREPRENEURSHIP AND SUSTAINABILITY ISSUES

ISSN 2345-0282 (online) http://jssidoi.org/jesi/

2018 Volume 8 Number 2 (December)

http://doi.org/10.9770/jesi.2018.8.2(32)

Nikitina, M. G. 2011. Geoekonomicheskaya strategiya Ukrainy v kontekste prichernomorskoi integratsii: Monografiya [Ukraine's geoeconomic strategy in the context of Black Sea integration: A monograph]. Simpferopol, Ukraine: DIAIPI.

Russian Federal State Statistics Service. (n.d.). Natsional'nye scheta [National accounts]. Retrieved from http://www.gks.ru/wps/wcm/connect/rosstat_main/rosstat/ru/statistics/accounts/.

Shchegolev, S. I., \& Shakhov, A. E. 2009. Metody ekonomicheskoi otsenki investitsii v innovatsii i pokazateli investitsionnogo analiza v svete faktornykh obstoyatel'stv ekonomicheskoi bezopasnosti Rossii [Methods for the economic assessment of investments and innovations and investment analysis indicators in light of factor circumstances surrounding Russia's economic security], Yuridicheskaya Nauka $i$ Praktika: Vestnik Nizhegorodskoi Akademii MVD Rossii, 2: 122-127.

Shvetsova, O. A.; Rodionova, E. A.; Epstein, M. Z. 2018. Evaluation of investment projects under uncertainty: multi-criteria approach using interval data, Entrepreneurship and Sustainability Issues 5(4): 914-928. https://doi.org/10.9770/jesi.2018.5.4(15)

Tvaronavičienè, M. 2018a. Toward efficient policy making: forecasts of vulnerability to external global threats, Journal of Security and Sustainability Issues 7(3): 591-600. https://doi.org/10.9770/jssi.2018.7.3(18)

Tvaronavičienè, M. 2018b. Preconditions of sustainable entrepreneurship: estimating of Brexit scenarios' impact on macroeconomic environment, Polish Journal of Management Studies 17 (2): 222-234 https://doi.org/10.17512/pjms.2018.17.2.19

Zhdanova, M. G. 2015. Problemnye aspekty investitsionnoŭ bezopasnosti Rossiǔskoŭ Federatsii [Problematic aspects of the investment security of the Russian Federation]. In Mezhdunarodnaya nauchno-tekhnicheskaya konferentsiya molodykh uchenykh BGTU im. V.G. Shukhova [Proceedings of International Scientific/Technical Conference for Young Scientists at Shukhov Belgorod State Technological University]. Belgorod, Russia: BGTU, 3751-3755.

Marina Gennadievna NIKITINA

ORCID ID: https://orcid.org/0000-0001-5777-2288

Viktoriya Viktorovna POBIRCHENKO

ORCID ID: https://orcid.org/0000-0001-6234-5678

Elena Alekseevna SHUTAIEVA

ORCID ID: https://orcid.org/0000-0003-1838-5546

Anna Ivanovna KARLOVA

ORCID ID: https://orcid.org/0000-0003-0569-1018

Register for an ORCID ID:

https://orcid.org/register

Copyright (C) 2018 by author(s) and VsI Entrepreneurship and Sustainability Center

This work is licensed under the Creative Commons Attribution International License (CC BY).

http://creativecommons.org/licenses/by/4.0/

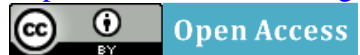

